\title{
ANALISA KINERJA MESIN OVEN PENGERING BUAH BERKAPASITAS 1 KG
}

\author{
Adi Saputra \\ Program Studi Teknik Mesin, Fakultas Teknik, Universitas Muhammadiyah Riau \\ Jalan Tuanku Tambusai Ujung, Kecamatan Tampan, Kelurahan Delima, Kota Pekanbaru, Riau 28291 \\ E-mail: Adisaputra875@yahoo.com
}

\begin{abstract}
One way to process pineapples, pineapples are classified as highly perishable and rotten foods. For this reason, it is necessary to handle fruit to save the abundance of fruit that occurs during harvest. One example of what the community has done is dealing with the abundant harvest of pineapples by making fruit as a daily snack, namely getting dry fruit products that are ready to eat by making pineapple chips. The production of fruit kiripik is usually done by frying which is done by frying which contains oil which is usually called conventional frying. Therefore, with this oven drying machine, it can help the community in making pineapple chips. The purpose of this study was to determine the moisture content in the manufacture of pineapple chips in a drying oven machine, to analyze the ratio of temperature settings that were set 95 to 110 in the drying process. The fastest drying time is achieved at drying at a drying temperature of $110^{\circ} \mathrm{C}$.
\end{abstract}

Keywords: chips, pineapples, temperature, dryer

\section{Abstrak}

Salah satu cara untuk penggolahan buah nenas, Buah nenas digolongkan bahan pangan yang sangat mudah rusak dan busuk. Untuk itu perlu adanya penanganan buah untuk menyelamatkan keberlimpahan buah yang terjadi saat panen. Salah satu contoh yang dilakukan masyarakat menangani hasil panen buah nenas yang berlimpah dengan menjadikan buah sebagai bahan cemilan sehari hari yaitu mendapatkan produk buah yang kering dan siap santap dengan di buatnya keripik buah nenas. Produksi kiripik buah biasanya dilakukan dengan penggorengan yang dilakukan dengan cara pengorengan yang berisi minyak biasanya disebut dengan penggorengan konvensional. Maka dari itu dengan adanya mesin oven pengering ini dapat membantu masyarakat dalam pembuatan keripik buah nenas. Tujuan dari Penelitian ini adalah untuk Mengetahui kadar air dalam pembuatan keripik buah nenas pada mesin oven pengering, Menganalisa perbandigan pengaturan temperature suhu yang di stel $95^{\circ} \mathrm{C}$ sampai dengan $110^{\circ} \mathrm{C}$ dalam proses pengeringan. Waktu pengeringan paling cepat di capai pada pengeringan suhu pengeringan $110^{\circ} \mathrm{C}$.

Kata Kunci : keripik, nenas, temperatur, mesin pengering

\section{Pendahuluan}

Salah satu bidang industri yang berperan besar terhadap pembangunan nasional adalah Usaha Mikro, Kecil dan Menengah (UMKM). Berdasarkan data BPS 2014, UMKM merupakan sektor penyerap tenaSSSga kerja terbesar dari total angkatan kerja yang dimiliki saat ini sebanyak 125 juta orang. Dari sisi jumlah unit usaha, sektor UMKM tercatat menguasai $99 \%$ pangsa pasar sektor usaha atau mencapai 56 juta unit usaha dan $70 \%$ diantaranya merupakan UMKM pangan.UMKM pangan di propinsi riau tumbuh dengan subur.Salah satu di antaranya adalah UMKM industri Makanan seperti keripik . seperti keripik nenas yang di buat di kabupaten kampar di daerah kualu nenas. Buah nenas digolongkan bahan pangan yang sangat mudah rusak dan busuk. Untuk itu perlu adanya penanganan buah untuk menyelamatkan keberlimpahan buah yang terjadi saat panen. Salah satu contoh yang dilakukan masyarakat riau khususnya kabupaten kampar dalam menangani hasil panen buah nenas yang berlimpah yaitu dengan menjadikan buah sebagai bahan cemilan sehari hari yaitu mendapatkan produk buah yang kering dan siap santap yaitu keripik buah nenas 
Produksi kiripik buah biasanya dilakukan dengan penggorengan yang dilakukan dengan cara pengorengan yang berisi minyak biasanya disebut dengan penggorengan konvensional. Pada penggorengan ini dilakukan pada suhu yang cukup tinggi $\left( \pm 70-90^{\circ} \mathrm{C}\right)$ yaitu pada suhu didih minyak. Penggorengan pada suhu tinggi akan berdampak terhadap warna produk (mengalami reaksi pencokelatan atau browning) sehingga buah maupun buah-buahan yang digoreng secara konvensional akan kehilangan sebagian besar vitamin yang dikandungnya.

Mesin pengering ini mempunyai fungsi mengeringkan berbagai macam makanan sebagai

\section{Metode Penelitian}

Penelitian ini dilakukan dengan menggunakan metode deskriptif, data dari pengamatan disusun dalam bentuk tabel. Kemudian digambarkan dalam bentuk grafik lalu dibahas. Percobaan dilakukan 2 (dua ) kali.

1. Modefikasi Alat Pengering Tipe Rak

Alat pengering tipe rak ini memiliki tinggi $600 \mathrm{~mm}$, panjang $800 \mathrm{~mm}$ dan lebar $700 \mathrm{~mm}$. Dibagian luar dinding dan dalam alat ini dilapisi dengan plat aluminium $0,8 \mathrm{~mm}$ dan di tengahtengah plat aluminium sekelilingnya di lapiskan gasbul sebagai penahan panas Di dalam alat dibuat 6 rak untuk meletakan buah nenas yang akan dikeringkan,dan penambahan blower untuk mendiginkan udara di dalam ruang.

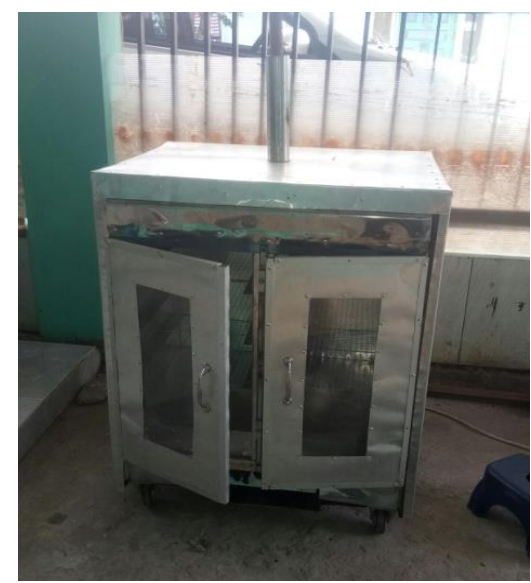

Gambar 1. Oven Pengering setelah di modifikasi proses pengganti sinar matahari. Keuntungan dari mesin oven pengering ini adalah menghasilkan hasil keripik yang tidak mengandung minyak, lebih tahan lama dan lebih kering, lebih renyah, tampil lebih menarik dan rasa lebih enak dibandingkan dengan penggorengan konvensional. Bentuk produk inilah yang disukai konsumen dan bisa menjadi karakteristik produk keripik siap santap dari buah nenas dengan kualitas nutrisi yang masih terjaga dan secara organeoleptik dapat diterima. Maka dari itu peneliti melakukan penelitian menggunakan metode oven pengering pada keripik buah nenas

\section{Pelaksanaan Penelitian}

Penelitian dimulai dengan menyiapkan semua bahan dan alat yang akan digunakan. Kadar air sampel diukur pada awal dan pada akhir penelitian. Selajutnya menimbang berat total bahan dimasing - masing rak lalu masukan dan letakan bahan buah nenas yang akan dikeringkan diatas rak pengering. Suhu pengering pada penelitian ini diatur sebesar $95^{\circ} \mathrm{C}$ termocouple ada empat titik yang di letak di temperatur ruang, temperature buah, temperature dinding bagian luar,dan temperature kompor.

Tinggi rendahnya suhu diatur dari besar kecilnya nyala api, regulator yang dipakai khusus untuk mengontrol keluarnya gas dari tabung dan kecepatan udara dari blower. Blower akan hidup jika suhu temperature ruang ketika posisi suhu sekitar $95^{\circ} \mathrm{C}$ dan pengujian yang ke dua temperature suhu di atur sekitar $110^{\circ} \mathrm{C}$ Bahan sampel ditimbang kembali untuk mengetahui penurunan berat. Pengamatan ini dilakukan sampai buah tadi sudah berubah warna ke coklatan .

\section{Variabel Pengamatan}

Hal - hal yang diamati adalah sebagai berikut :

1. Suhu udara ruangan

2. Suhu bahan

3. Suhu kompor

4. Suhu bagian dinding luar

5. Penurunan berat bahan

6. Penurunan kadar air bahan

4. Prosedur Pengamatan

Suhu Suhu dianalisis berdasarkan hasil pengamatan yang disusun dalam bentuk tabel . Suhu buah,suhu ruangan dalam dan dinding luar dan kompor di ukur melalui termocople . 


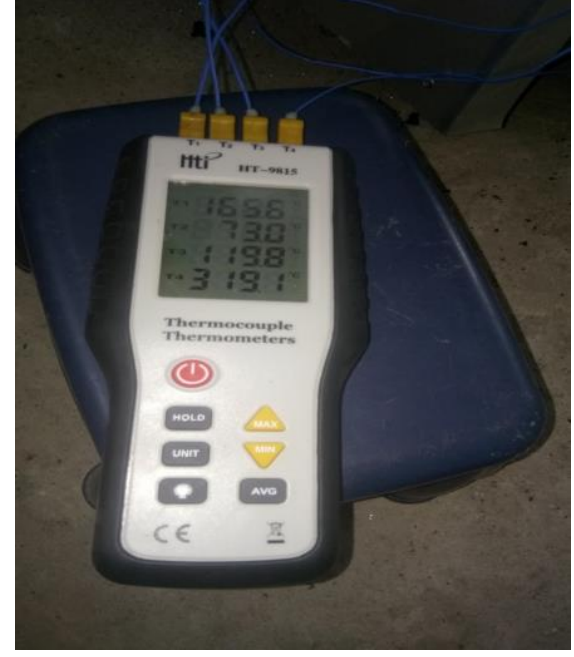

Gambar 2. Pengambilan Data Temperature Suhu Di Termocouple

5. Analisa Penurunan Berat Bahan

Penurunan berat bahan dianalisis dengan menimbang berat bahan sampel berat awal

\section{Hasil Dan Pembahasan}

\subsection{Proses Pengeringan Buah Nenas}

Pengujian ini dilakukan dengan cara memilih buah nenas yang sudah masak karena ketikah di buat jadi keripik rasanya lebih enak, setelah itu buah nenas di kupas kulitnya dan di iris-iris , tahap pertama tidak di buang jantung tengah buah nenas ,sedangkan tahap ke dua di buang jantung tengahnya.

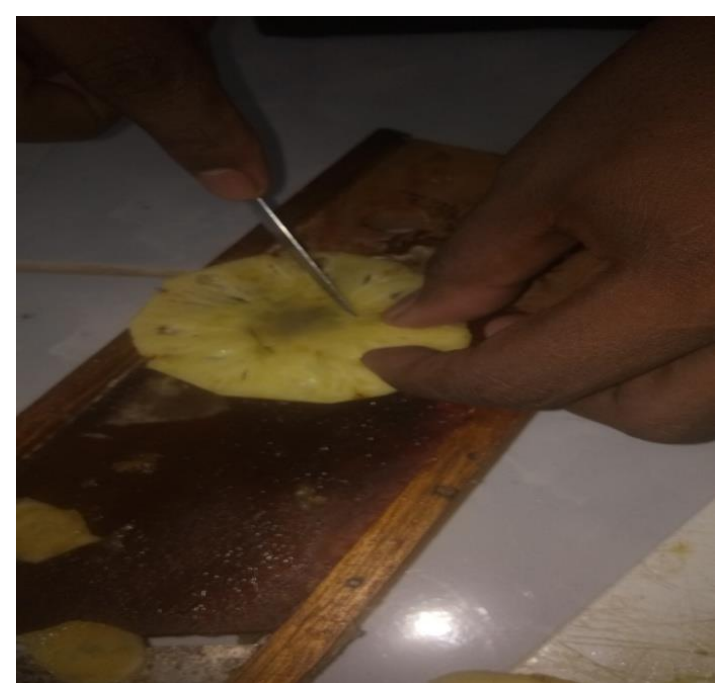

penurunan bahan sampai bahan menjadi kering menyusun data hasil pengamatan dalam bentuk tabel.

\section{- Kadar Air Awal}

Dalam hal ini terdapat dua metode untuk menentukan kadar air bahan tersebut yaitu berdasarkan bobot kering (dry basis) dan berdasarkan bobot basah (wetbasis). Kadar air basis basah dapat ditentukan dengan persamaan berikut : $m=\frac{W m}{w m+w d} \times 100 \%$

Dimana : $\mathrm{m}=$ Kadar air basis basah $(\%)$

$\mathrm{Wm}=$ Berat air dalam bahan $(\mathrm{gr})$

$\mathrm{Wd}=$ Berat bahan kering mutlak (gr)

Kadar air berat kering dapat ditentukan dengan persamaan berikut :

$m=\frac{W m}{w d} \times 100 \%$

Dimana: $\quad \mathrm{M}=$ Kadar air basis kering $(\%)$

$\mathrm{Wm}=$ Berat air dalam bahan $(\mathrm{gr})$

$\mathrm{Wd}=$ Berat bahan kering mutlak (gr)

Langkah selanjutnya dilakukan penimbangan buah nenas yang telah di iris iris tadi dengan timbangan digital ,Buah nenas tahap pertama dengan berat 53 gram, dan tahap ke dua dengan berat 41,2 gram .

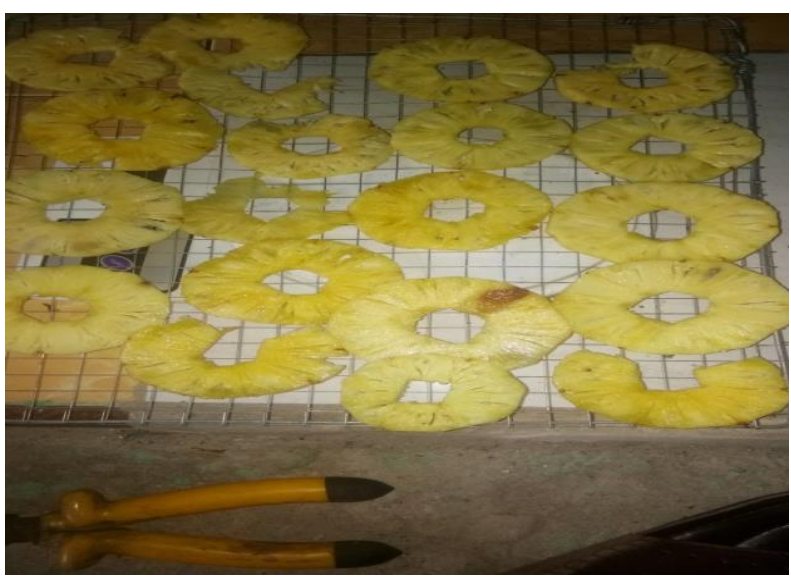

Gambar 4. Proses penimbangan buah nenas

Proses selanjutnya memasukan buah nenas yang sudah tersusun rapi di loyang di masukan ke dalam ruang oven,dan memasang cabel yang terhubung di termocouple pada buah, pada ruang dalam ,dinding luar, dan kompor , setelah itu menutup pintu oven dengan rapat dan di kunci,

Gambar 3. Proses Pembuangan Jantung Nenas

SURYA TEKNIKA Vol. 7 No. 2, Desember 2020: 147-155 
Pengaturan thermostat proses peng ujian mengatur suhu ruang pemanas pada suhu $95^{\circ} \mathrm{C}$

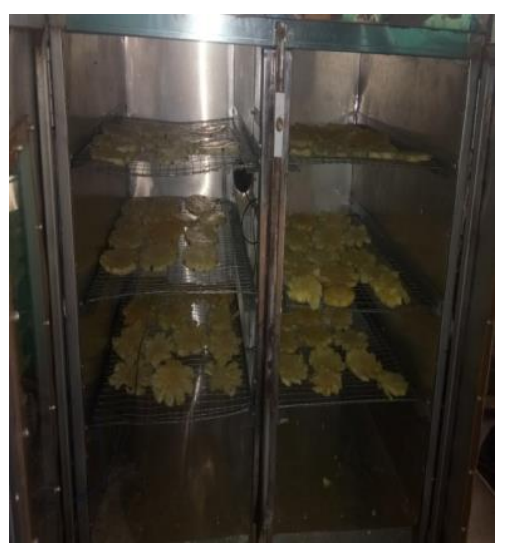

Gambar 5. Buah nenas di masukan ke oven Diagram dia atas di mulai dengan kompor sebagai bahan penghantar panas ke oven, di mulai dari bawah dan merambat ke sela- sela dinding oven ,kemudian panas tersebut menuju ke bagian atas oven ,proses pembakaran itu di manfaat kan terlebihdahulu sebelum keluar melalui cerobong ke udara bebas ,hasil dari panas kompor ,panas akan masuk ke dalam ruang oven secara konduksi dan memanaskan ruang dalam oven, agar panas di dalam merata maka diperluan udara dari blower sehingga udara tersebut menjadi panas untuk mensirkulasikan panas secara merata dan menjadikan uap jenuh di dalam ruang oven akibat penguapan kadar air dari buah nenas yang di keringkan .uap jenuh tersebut harus dibuang keudara bebas melalui cerobong uap jenuh .

\subsection{Hasil Pengujian Dan Pengolahan Data}

Pengujian ini di lakuakan dengan menggunakan alat termocouple dan untuk pengatur suhu di dalam ruang mengunakan alat termostat yang di stel $95^{\circ} \mathrm{C}$ jika posisi suhu sudah $95^{\circ} \mathrm{C}$ Blower akan mengembuskan udara ke ruang dalam untuk mendiginkan temperature suhu di dalam . 


\section{Tabel 1.}

Hasil Pengujian Temperature Suhu Tahap Pertama Dengan Pengaturan Suhu Ruang $95^{\circ} \mathrm{C}$.

\begin{tabular}{ccccc}
\hline Waktu & $\begin{array}{c}\text { Temperature } \\
\text { ruang dalam (T1) }\end{array}$ & $\begin{array}{c}\text { Temperature } \\
\text { Buah (T2) }\end{array}$ & $\begin{array}{c}\text { Temperature } \\
\text { ruang luar (T3) }\end{array}$ & $\begin{array}{c}\text { Temperature } \\
\text { kompor (T4) }\end{array}$ \\
\hline 11:25 & 153.5 & 66.3 & 112.6 & 301.4 \\
$11: 35$ & 166.3 & 75.4 & 120.1 & 317.8 \\
$11: 45$ & 169.7 & 70.4 & 123.3 & 315.7 \\
$11: 55$ & 162.7 & 68.1 & 115.3 & 296.9 \\
$12: 05$ & 170.3 & 68.8 & 103.9 & 291.8 \\
$12: 15$ & 153.4 & 69.8 & 107.3 & 296.2 \\
$12: 25$ & 148.5 & 68.1 & 102.8 & 293.3 \\
$12: 35$ & 141.0 & 69.8 & 92.3 & 281.0 \\
$12: 45$ & 125.3 & 66.3 & 90.8 & 274.6 \\
$12: 55$ & 121.6 & 56.3 & 87.5 & 271.5 \\
$13: 05$ & 117.8 & 59.8 & 85.5 & 271.7 \\
$13: 15$ & 127.6 & 62.2 & 88.3 & 271.5 \\
$13: 25$ & 116.6 & 64.7 & 84.8 & 237.8 \\
$13: 35$ & 97.4 & 83.8 & 62.5 & 284.5 \\
$13: 45$ & 132.3 & 76.8 & 86.3 & 270.8 \\
$13: 55$ & 114.3 & 87.6 & 77.9 & 258.8 \\
$14: 05$ & 125.3 & 92.5 & 81.4 & 362.3 \\
$14: 15$ & 114.6 & 77.5 & 72.5 & 347.5 \\
$14: 25$ & 115.5 & 84.8 & 75.1 & 332.2 \\
$14: 35$ & 100.5 & 90.4 & 67.6 & 241.4 \\
$14: 45$ & 125.2 & 105.2 & 83.4 & 319.4 \\
$14: 55$ & 119.9 & 96.8 & 76.1 & 244.8 \\
$15: 05$ & 107.2 & 92.1 & 69.1 & 256.3 \\
$15: 15$ & 102.8 & 91.3 & 67.3 & 243.8 \\
$15: 25$ & 127.8 & 118.3 & 76.6 & 258.6 \\
& & & &
\end{tabular}

\subsection{Analisa Data Temperature Suhu}

Dari hasil penelitian temperature suhu dengan waktu perbandingan per 10 menit dengan mengunakan termocouple, Temperature Suhu Ruang Dalam suhu tertinggi sampai $170.3^{\circ} \mathrm{C}$ dan suhu terendah $97,4^{\circ} \mathrm{C}$. Temperature Suhu
Buah,suhu tertinggi $118,3^{\circ} \mathrm{C}$,Dan suhu terendah $56,3^{\circ} \mathrm{C}$. Temperature ruang luar,suhu tertinggi mencapai $123,3^{\circ} \mathrm{C}$, dan suhu terendah $62,5^{\circ} \mathrm{C}$ dan untuk temperature suhu kompor ,suhu tertinggi mencapai 362,3 ,dan suhu terendah $237,8^{\circ} \mathrm{C}$.

SURYA TEKNIKA Vol. 7 No. 2, Desember 2020: 147-155 
Tabel 2. Hasil Pengujian Temperature Suhu Dengan Pengaturan Suhu Ruang $110^{\circ} \mathrm{C}$

\begin{tabular}{|c|c|c|c|c|}
\hline waktu & $\begin{array}{c}\text { Temperature ruang } \\
\text { dalam(T1) }\end{array}$ & $\begin{array}{c}\text { Temperature } \\
\text { Buah (T2) }\end{array}$ & $\begin{array}{c}\text { Temperature } \\
\text { ruang luar (T3) }\end{array}$ & $\begin{array}{l}\text { Temperature } \\
\text { kompor(T4) }\end{array}$ \\
\hline $15: 40$ & 92,2 & 70,6 & 67,1 & 249,8 \\
\hline $16: 00$ & 95,1 & 68,1 & 64,1 & 258,1 \\
\hline $16: 10$ & 101,8 & 71,1 & 69,3 & 241,4 \\
\hline $16: 20$ & 84,4 & 62,3 & 50,4 & 234,7 \\
\hline $16: 30$ & 110,1 & 86,7 & 75,4 & 216,7 \\
\hline $16: 40$ & 88,0 & 75,5 & 57,6 & 306,3 \\
\hline $16: 50$ & 129,3 & 106,4 & 91,1 & 184,0 \\
\hline 17:00 & 110,9 & 89,7 & 70,9 & 324,5 \\
\hline $17: 10$ & 115,2 & 92,6 & 80,6 & 178,7 \\
\hline $17: 20$ & 86,2 & 70,3 & 59,5 & 220,8 \\
\hline $17: 30$ & 102,7 & 69,8 & 67,6 & 231,2 \\
\hline $17: 40$ & 107,0 & 67,0 & 71,5 & 214,3 \\
\hline $17: 50$ & 80,3 & 51,4 & 53,8 & 224,8 \\
\hline $18: 00$ & 105,4 & 66,7 & 68,9 & 293,2 \\
\hline $18: 10$ & 80,2 & 68,3 & 50,7 & 236,3 \\
\hline $18: 20$ & 78,0 & 63,0 & 50,2 & 234,9 \\
\hline $18: 30$ & 0,2 & 70,1 & 57,1 & 233,9 \\
\hline $18: 40$ & 109,4 & 93,5 & 69,6 & 332,9 \\
\hline $18: 50$ & 102,2 & 87,4 & 62,3 & 340,2 \\
\hline $19: 00$ & 105,7 & 91,3 & 63,8 & 343,0 \\
\hline $19: 10$ & 106.7 & 91,5 & 64,4 & 351,1 \\
\hline $19: 20$ & 108,7 & 92,7 & 65,2 & 352,6 \\
\hline $19: 30$ & 92,2 & 81,5 & 58,6 & 346,3 \\
\hline $19: 40$ & 75,2 & 69,8 & 51,6 & 271,4 \\
\hline
\end{tabular}

SURYA TEKNIKA Vol. 7 No. 2, Desember 2020: 147-155 
Dari data hasil penelitian temperature suhu dengan penggaturan suhu ruang $110^{\circ} \mathrm{C}$, dan untuk pengambilan data temperature suhu per 10 menit dengan mengunakan termocouple .untuk temperature suhu ruang yang tertinggi mencapai $129,3^{\circ} \mathrm{C}$, dan terendah $75,2^{\circ} \mathrm{C}$ untuk temperature buah yang tertinggi mencapai $106,4^{\circ} \mathrm{C}$,dan terendah mencapai $51,4^{\circ} \mathrm{C}$. untuk temperature suhu ruang luar suhu tertinggi mencapai $80,6^{\circ} \mathrm{C}$ dan suhu terendah $50,4^{\circ} \mathrm{C}$. Untuk temperature suhu kompor ,suhu tertinggi mencapai $352,6^{\circ} \mathrm{C}$, dan untuk suhu terendah mencapai $184,0^{\circ} \mathrm{C}$

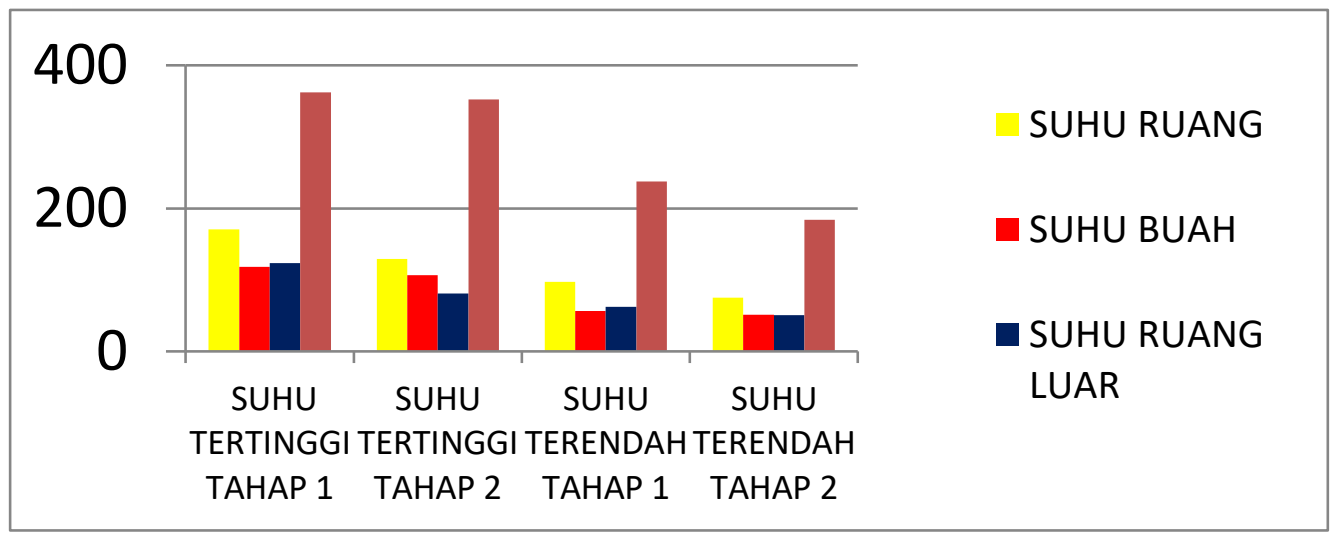

Grafik 1. Perbandingan Temperature Suhu Tahap Pertama Dan Ke Dua

\subsection{Analisa Hasil Data}

Dari hasil penelitian tahap pertama dan tahap ke dua bahwasanya degan temperature suhu $95^{\circ} \mathrm{C}$ per 10 menit melebihi rata-rata melebihi $110^{\circ} \mathrm{C}$ di karena blower sebelum 10 menit sudah hidup untuk menghembuskan udara ke dalam ruang.

sedang kan temperature suhu ruang yang di stel $110^{\circ} \mathrm{C}$ ke blower ,per 10 menit sudah hidup mengembuskan udara ke ruang dalam.

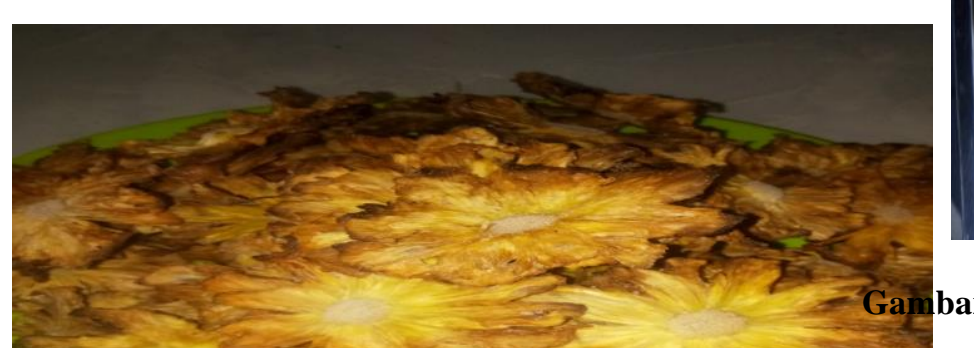

ambar 7. Hasil Pengeringan Buah Neneas Tahap ke Dua

Analisa kadar air

Tahap Pertama Yaitu : Pengeringan buah nenas tahap pertama degan pengaturan suhu $95^{\circ} \mathrm{C}$, degan tidak membuang jantung tengah yang ada di buah

SURYA TEKNIKA Vol. 7 No. 2, Desember 2020: 147-155 
nenas dengan waktu 4 jam.

Berat buah nenas sebelum di oven : 53 gram

Berat buah nenas setelah di oven : 7,7 gram

KADARAIR $=\frac{\text { BERAT AWAL }- \text { BERAT AKHIR }}{B E R A T \text { AWAL }} \mathrm{x}$

$$
100 \%
$$

$$
=\frac{53-7.7}{53} 100 \%
$$

Tahap Kedua : Pengeringan buah nenas tahap ke dua degan pengaturan suhu $110^{\circ} \mathrm{C}$, degan membuang jantung tengah yang ada di buah nenas

dengan waktu 4 jam Berat buah nenas sebelum di oven : 41,2 gram.

Berat buah nenas sesudah di oven : 6,3 gram

$$
=\frac{\text { BERAT AWAL }- \text { BERAT AKHIR }}{\text { BERAT AWAL }} X 100 \%
$$

$$
\begin{aligned}
& =\frac{45.3}{53} 100 \% \\
& =0.8547 \times 100=85.47 \%
\end{aligned}
$$

$$
\begin{aligned}
& =\frac{41.2-6.3}{41.2} \times 100 \% \\
& =\frac{34.9}{41.2} \times 100
\end{aligned}
$$

$$
0.8470 \times 100=84.70 \%
$$

Tabel 3. Hasil Karakteristik Alat

\begin{tabular}{|c|c|c|c|c|}
\hline $\begin{array}{c}\text { Temperature } \\
\text { suhu }\left({ }^{\circ} \mathbf{C}\right)\end{array}$ & $\begin{array}{c}\text { Berat } \\
\text { awal } \\
(\text { gram })\end{array}$ & $\begin{array}{c}\text { BERAT } \\
\text { Akhir } \\
(\text { gram })\end{array}$ & $\begin{array}{l}\text { Kadar } \\
\text { air } \\
(\%)\end{array}$ & $\begin{array}{c}\text { Air } \\
\text { yang } \\
\text { Di } \\
\text { uapkan } \\
(\text { Gram })\end{array}$ \\
\hline 95 & 53 & 7.7 & 85.47 & 45.3 \\
\hline 110 & 41.2 & 6.3 & 87.70 & 34.9 \\
\hline
\end{tabular}

Terlihat bawah semakin tinggi suhu pengeringan semakin rendah kadar air buah nenas, dan semakin cepat pulak terjadi pengeringan dengan di buang

\section{Kesimpulan dan Saran}

Dari hasil penelitian pengeringan buah nenas dengan mengunakan elemen pemanas dan blower dapat di simpulkan bahwa :

Dari pengujian penelitian temperature suhu $95^{\circ} \mathrm{C}$ dengan berat buah sebelum nya 53 gram Sebelum di keringkan dan setelah di keringkan menjadi 7,7 gram dan dapat mengurangi kadar air yang ada di buah nenas dengan waktu 4 jam dengan penggurangan kadar air $688 \%$. dan untuk temperature $110^{\circ} \mathrm{C}$ dengan berat bahan sebelum di keringkan sekitar 41.2 gram nya jantung tengah nenas juga mempercepat pengeringan buah nenas.

SURYA TEKNIKA Vol. 7 No. 2, Desember 2020: 147-155 
Setelah melakukan pengujian pada mesin pengering buah nenas dengan dua kali percobaan maka dapat memberikan saran untuk kedepanya ,adapun saran yang di berikan adalah sebagai berikut :

1. Perlu dilakuannya penelitian kualitas warna pada keripik nenas yang di keringkan oleh oven pengering.
2. Perlu dilakukanya penelitian lebih lanjut dengan kapasitas lebih besar dengan waktu yang lebih singkat dengan hasil yang lebih baik agar alat pengering ini dapat di pakai masyarakat.

\section{DAFTAR PUSTAKA}

[1] Harrison, (2010). pengeringan degan oven mengunakan udara panas.

OvenLaboratorium(Anugrahniagamandiriblog.201 8)

[2] Rahmawan, 2011. Pengeringan, pendiginan dan pengemasan komoditas pertanian". Direktorat pendidikan kejuaraan. Jakarta . Brooker, D.B; F.W.B Arena ;c. Hall 1957 .Drying Cereal Grain. The AVI Publishing co inc., Wesport, Connecticut

[3] Rakhmadiono, s. 1995. Risalah Hasil penelitian penanganan Hasil pertania.Universitas

Brawijaya.malang.
[4]Brooker, D.B; F.W.B Arena ;c. Hall. 1992 .Drying and Storage of Grain and Oilseeds.An AVI book.

[5] Simmonds, W.H.C.,G.T Ward and Ewen McEwen.1953.The Drying of wheat grain.part 1: The Mechanism of Drying. Transactions of the Institution of Chemmical Engineers.

[6] Nurba, D.2010.”Analisis Distribusi Suhu, Aliran Udara,RH,dan kadar air dalam In-Store Dryer (ISD) untuk biji jagung".Institut pertanian 